\title{
Tectonic Position of the Alshar Au-As-Sb-Tl Deposit, Macedonia
}

\author{
N. T. Kochneva ${ }^{1}$, A. V. Volkov', T. Serafimovski', \\ G. Tasev ${ }^{2}$, and Corresponding Member of the RAS I. N. Tomson ${ }^{1}$
}

Received September 20, 2005

DOI: $10.1134 /$ S1028334X06020036

During the second half of the 20th century, several dozen large and medium deposits of disseminated pyrite-marcasite ores with total gold reserves of more than $6000 \mathrm{t}$ and annual gold production of $\sim 200 \mathrm{t}$ were found in the Basin and Range Province, Nevada, United States $[1,2]$. This unique gold district is termed as the Carlin trend. The limited development of the Carlintype mineralization in other gold districts of the world is presently a debated issue. Naturally, each Carlin-type mineralization inferred beyond Nevada requires detailed investigations. In 2004, we began to study the Alshar deposit with Carlin-type mineralization together with Macedonian geologists [3]. The Alshar deposit is a large object in terms of $\mathrm{Tl}$ reserves and a medium reserve in terms of inferred Au reserves [3, 4].

The territory of Macedonia experienced long-term geological evolution. Its majority is occupied by the Serbian-Macedonian and Pelagonia crystalline massifs, separated by the Mesozoic Vardarian riftogenic graben (Fig. 1). Macedonia is located in the SerbianMacedonian part of the Eurasian Tethys metallogenic belt. Mineralization related to the Cenozoic activation in this area is expressed in the formation of volcanoplutonic associations in the dispersed spreading environment [4]. The activation spanned the Serbian-Macedonian Massif and part of the Vardarian riftogenic zone. Superimposed structures of this period occur as narrow NW-trending grabenlike depressions complicated by local ring structures of the chamber type.

Previous joint works with Macedonian geologists showed that the present-day tectonic structure of Mace-

\footnotetext{
${ }^{1}$ Institute of Geology of Ore Deposits, Petrography, Mineralogy, and Geochemistry, Russian Academy of Sciences, Staromonetnyi per. 35, Moscow, 119017 Russia; e-mail: alexandr@igem.ru

${ }^{2}$ Faculty of Mining and Geology, Kiril and Methodie University of Skopje, Goce Delcev 89, 92000 Shtip, Macedonia
}

donia reflects dislocations closely related to Cenozoic magmatism and productive mineralization. These dislocations were reconstructed from tectonic elements of the present-day relief surface using morphostructural analysis and deciphering aerial and satellite photographs. Based on the dislocations, we distinguished three (Oligocene-Miocene) NW-trending metallogenic zones superimposed onto the metamorphic sequence of the Serbian-Macedonian Massif. They are mainly composed of the Cenozoic tuffogenic-sedimentary and volcanic sequences and are crosscut by granitoids and dikes of intermediate composition. The metallogenic zones compose an ore belt (Fig. 1), which extends to the northwest (Serbia) and southeast (Greece and Bulgaria).

From southwest to northeast, the metallogenic zones show variation in ore type and decrease in age of magmatic complexes and ores. One can see a distinct correlation between age and ore composition. Northeastward, the mineralization evolves from high-temperature (relatively low-sulfide) to low-temperature (polysulfide) types. The directed change of ore composition can be related to differentiation of ore matter in the deep-seated chambers. The ore type changes across metallogenic zones in the following way: skarn-magnetite ores (Borov Dol deposit), porphyry copper ores (Buchim), base metal copper ores (Kratovo-Zletovo), and base metal ores (Sasa and Toranica). In the SW-NE direction, the age of ore-magmatic clusters varies in the following order: 28-24.5 Ma (Borov Dol-Buchim district), 27.2-16 Ma (Kratovo-Zletovo district), and 24$12 \mathrm{Ma}$ (Sasa-Toranica district). Deposits of the latter district are the youngest ones. Thus, one can see a distinct compositional trend caused by decreasing age and differentiation. These features suggest the existence of a link between the metallogenic zones at depth.

The Pliocene Kozuf-Arid metallogenic zone extending along the Greek-Macedonian boundary (Fig. 1) is located in southernmost Macedonia. In addition to the Alshar deposit, this zone also incorporates several 


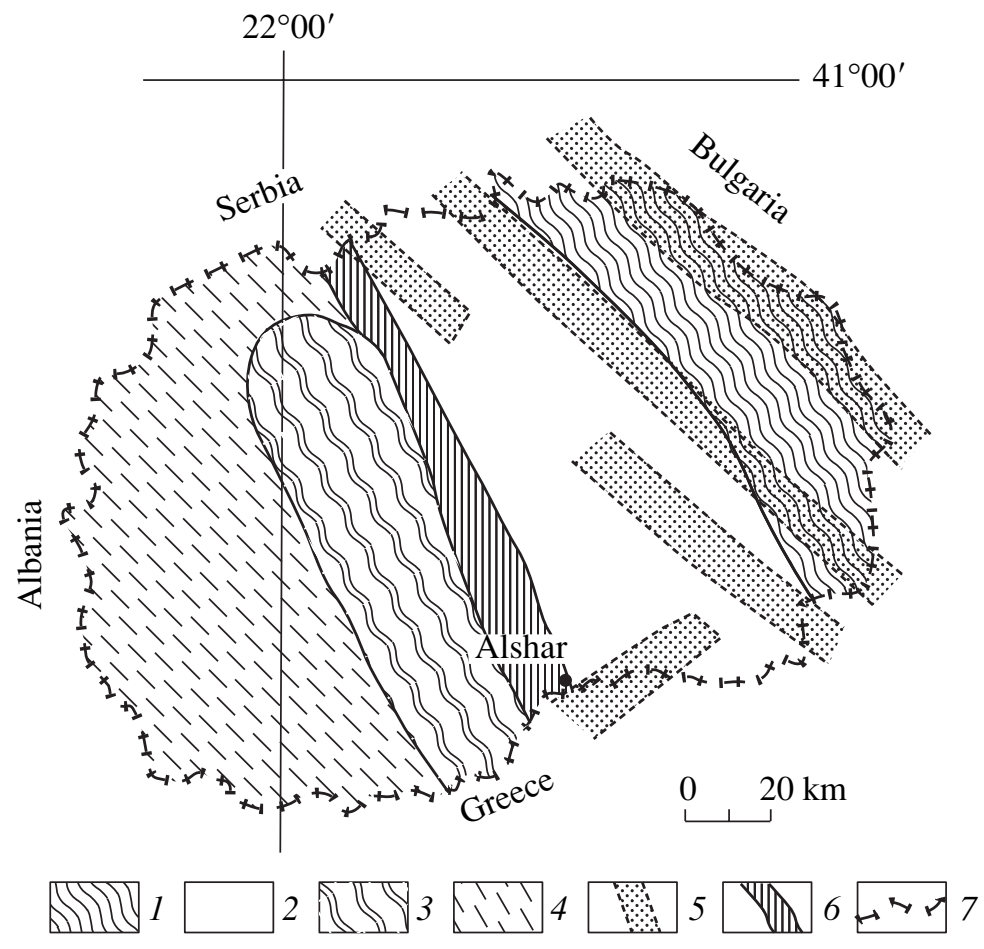

Fig. 1. Tectonic scheme of Macedonia. (1) Serbian-Macedonian Massif; (2) Vardarian riftogenic graben; (3) Pelagonia Massif; (4) West Macedonian area; (5) Cenozoic metallogenic zones and fault systems; (6) Vardarian metallogenic zone; (7) boundary of the Macedonia Republic

$\mathrm{Sb}-\mathrm{As}-\mathrm{Au}$ occurrences, porphyry copper deposits, and native sulfur occurrences. The mineralization is distinctly related to the Pliocene volcanoplutonic complex developed along the main regional fault zone between the Pelagonia crystalline block on the west and Vardar zone on the east. The rock complex includes different types of andesites and quartz latites. Volcanic and plutonic activity lasted from 7 to $1.8 \mathrm{Ma}$ [4].

Ore mineralization at the Alshar deposit is developed as mineralized breccia at the contact of volcanic cover with dolomites, jasperoid beds in the carbonate rocks, and vein-disseminated zones in dolomites and Tertiary volcanic rocks.

The Alshar deposit includes several ore bodies with specific geochemical association of elements and composition. This is the only deposit in Macedonia, which has economic-grade contents of $\mathrm{Tl}(0.1-0.5 \%), \mathrm{Sb}$ (up to $2.5 \%)$, As $(1.5 \%)$, and gold ( $>1 \mathrm{~g} / \mathrm{t})$. It should be noted that gold is unevenly distributed in the ores. The highest Au contents (3-4 g/t; occasionally, up to $20 \mathrm{~g} / \mathrm{t}$ or more) were found in jasperoid zones in the southern part of the deposit [3].

By analogy with the Carlin-type deposits in Nevada, Percival and Radtke [3] distinguished four economicgrade types of gold ores at the Alshar deposit: (1) Sb$\mathrm{Au}$ jasperoid ore $(+\mathrm{Au}+\mathrm{As}+\mathrm{Tl})$; (2) siliceous gold ore $(+\mathrm{Au}+\mathrm{Sb}+\mathrm{Tl}) ;(3) \mathrm{As}-\mathrm{Au}$ ore $(+\mathrm{Tl}+\mathrm{Hg}+\mathrm{Sb}+\mathrm{Au})$; and (4) $\mathrm{Tl}$ ore.
The ores form three mineral assemblages of different ages: pyrite-marcasite, antimonite, and orpimentrealgar-lorandite.

The tectonic position of the Alshar deposit area was deciphered with morphostructural analysis and satellite images. First, we determined the present-day structural-tectonic plan of the southern part of Macedonia. For this purpose, we applied the known method of morphotectoisohypse, which implies subsequent generalization of contour lines and analysis of the river network. Analyzing the present-day surface with differentorder structural elements of the relief, structures of different taxonomic ranks were outlined.

The Alshar deposit is located at upper reaches of the Rozhdenska River (right tributary of the Crna river). The streams in the Rozdenska River basin form a nearly ideal radial-centripetal pattern on the plan (Fig. 2). U-shaped ridges from 1500 to $1800 \mathrm{~m}$ high outline the radialcentripetal river channels. The ridges are followed by U-shaped valleys. Such an orography suggests an endogenous ring structure $(18 \times 15 \mathrm{~km}$ across $)$ with a relatively subsided central part and uplifted peripheral belt. The ring structure is situated at the intersection of two extended diagonal deep-seated fault zones. The northwestern fault belongs to the Vardar zone. The northeastern fault deciphered from linear anomalies of color in the satellite image is emphasized by linearity of the Boshavica River valley, bends in the present-day relief, and a chain of domal structures no more than 

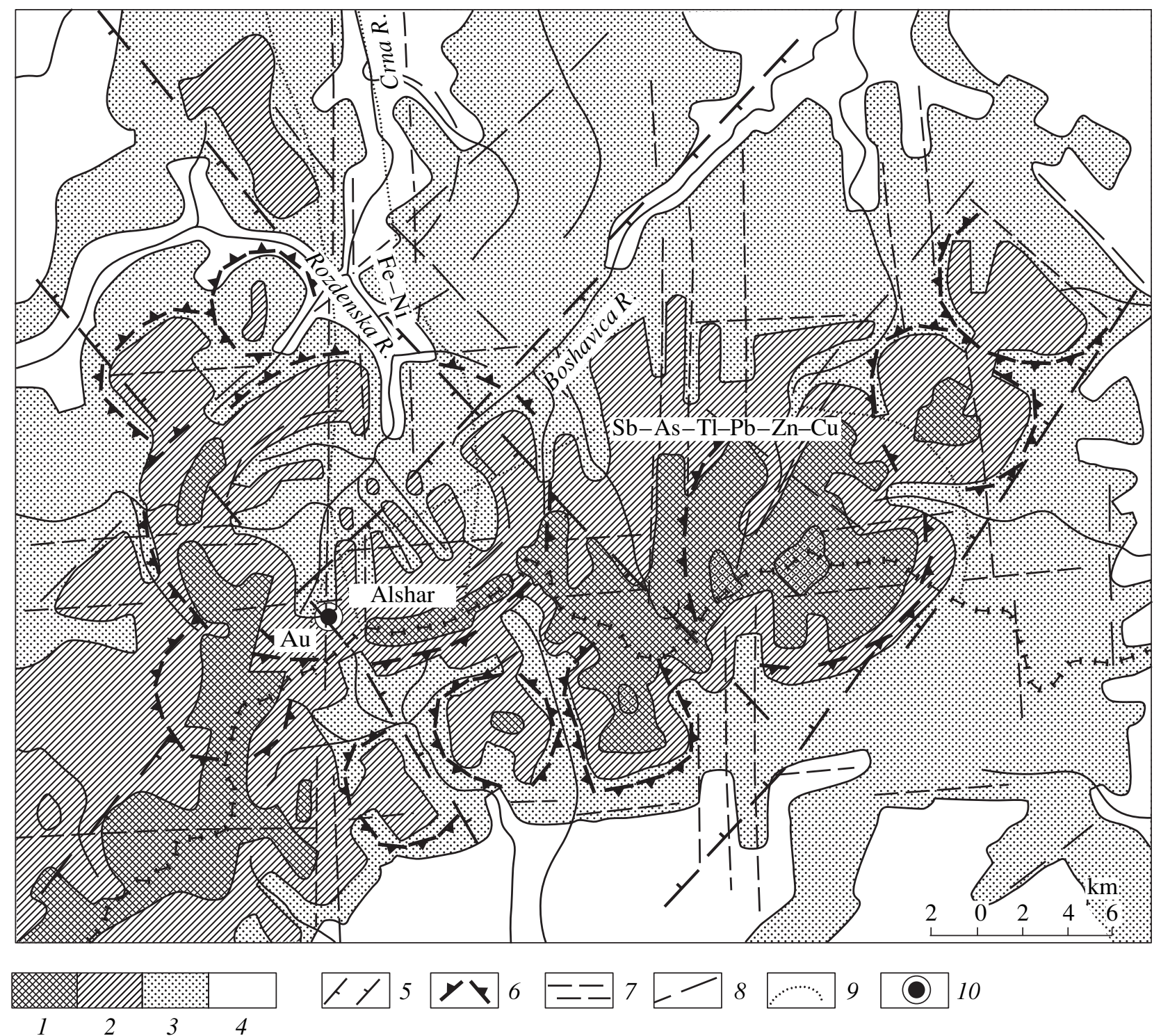

Fig. 2. Morphostructures of southern Macedonia. Hypsometric levels (m): (1) 1500-2000, (2) 1000-1500, (3) 500-1000, (4) below 500; (5) zones of diagonal dislocations; (6) boundaries of ring structures; (7) orthogonal deep-seated faults; (8) other faults; (9) geochemical halos; (10) Alshar deposit.

$10 \mathrm{~km}$ across. In addition, one can also see a system of the younger NE-trending faults with related Pliocene volcanic flows. The Alshar ring structure is rimmed by a belt of subordinate domes no more than $5 \mathrm{~km}$ across along its periphery. Each of these structures can be comparable with the associated ore-hosting magma chambers (Fig. 2). Three subordinate domes located south of the Alshar structure in Greece have the most complex structure and contrast morphology. By analogy with other studied regions, such associated structures host large ore districts and deposits [5].

The tectonic position of the Alshar deposit is emphasized by the morphology of geochemical halos. The Fe-Ni halo extends along the Vardar zone, while the $\mathrm{Sb}-\mathrm{As}-\mathrm{Tl}-\mathrm{Pb}-\mathrm{Zn}-\mathrm{Cu}$ halo coincides with the youngest NE-trending fault system that extends across the Oligocene and Miocene metallogenic zones (Fig. 2).

According to Yankovic [4], the main ore-controlling structure of the Alshar deposit is represented by the very wide and extended meridional fracture zone, which is radial with respect to the ring structure. At the same time, satellite image of the deposit shows a latitudinal fault zone that also represents a fragment of the large and extended system.

Thus, morphostructural analysis and deciphering of satellite images showed that the Alshar deposit is confined to the central part of the ring structure located at the intersection of two large diagonal fault zones, which host mineralization of different ages. The deposit occupies a special structural position within southern 
Macedonia. Geological, geochemical, and morphostructural investigations indicate that this structure represents a center of long-term endogenous activity, which appeared in Jurassic-Cretaceous and evolved during subsequent epochs.

\section{ACKNOWLEDGMENTS}

This work was supported by the Russian Foundation for Basic Research, project nos. 03-05-64095, 03-05-64334, 04-05-64359.

\section{REFERENCES}

1. A. H. Hofstra and J. S. Cline, Rev. Econ. Geol. 13, 163 (2000).

2. T. G. Theodore, B. B. Kotlyar, D. A. Singer, et al., Econ. Geol. 98, 287 (2003).

3. T. J. Percival and A. Radtke, Can. Mineral., No. 32, 649 (1994).

4. S. Jankovic, Neues Jahrb. Mineral. Abh. 166, 25 (1993)

5. A. V. Volkov and A. A. Sidorov, A Unique Gold District of Chukotka (Sev.-Vost. Kompleks. Nauch. Issled. Inst., Magadan, 2001) [in Russian]. 